\title{
Dukungan Sosial dan Postpartum Depression pada Ibu Suku Jawa
}

Social Support and Postpartum Depression in Javanese Mothers

\author{
Bunga Elsharon Wiyanto*1 \\ Fakultas Psikologi Universitas Kristen Satya Wacana \\ Krismi Diah Ambarwari \\ Fakultas Psikologi Universitas Kristen Satya Wacana
}

\begin{abstract}
Post-delivery becomes important, because the mother will be in a transition period of physical and psychological changes. During the transition period, the mother needs adjustment and during the adjustment period the mother is susceptible to stress and even depression. Symptoms of depression experienced by mothers after giving birth are known as postpartum depression. One of the factors associated with postpartum depression is social support. The purpose of this study was to examine the relationship between social support and postpartum depression in Javanese mothers after giving birth. The hypothesis of this study was that there was a negative relationship between social support and postpartum depression in Javanese mothers after giving birth. This study used a correlational quantitative research design and sampling using a purposive sampling technique on 34 postnatal Javanese mothers. The measuring instruments used in this study were the Edinburgh Postnatal Depression Scale (EPDS) and the Postpartum Social Support Questionnaire (PSSQ). The results showed the correlation coefficient $(r)=0.138$ with a value of $\operatorname{sig}=0.219(p<0.05)$. This means that there was no negative relationship between social support and postpartum depression in Javanese mothers after giving birth, so the hypothesis proposed in this study is not accepted.
\end{abstract}

Keywords: Javanese mother; postpartum depression; social support

\begin{abstract}
Abstrak. Pasca melahirkan adalah hal yang penting, karena ibu akan berada pada masa transisi dari perubahan fisik maupun psikologis. Pada masa transisi, ibu membutuhkan penyesuaian dan selama masa penyesuaian ibu rentan terkena stress bahkan depresi. Gejala depresi yang dialami oleh ibu pasca melahirkan dikenal dengan sebutan postpartum depression. Salah satu faktor yang berhubungan dengan postpartum depression adalah dukungan sosial. Penelitian ini bertujuan untuk menguji hubungan antara dukungan sosial dan postpartum depression pada ibu suku Jawa pasca melahirkan. Hipotesis dalam penelitian ini adalah terdapat hubungan negatif antara dukungan sosial dengan postpartum depression pada ibu suku Jawa pasca melahirkan. Penelitian ini menggunakan desain penelitian kuantitatif korelasional dan pengambilan sampel menggunakan teknik purposive sampling pada 34 ibu suku Jawa pasca melahirkan. Alat ukur yang digunakan dalam penelitian ini, yaitu: Edinburgh Postnatal Depression Scale (EPDS) dan Postpartum Social Support Questionnaire (PSSQ). Hasil penelitian menunjukkan koefisien korelasi $(r)=0,138$ dengan nilai sig $=0,219(\mathrm{p}<0,05)$. Artinya tidak terdapat hubungan negatif antara dukungan sosial dengan postpartum depression pada ibu suku Jawa setelah melahirkan, sehingga hipotesis yang diajukan dalam penelitian ini tidak diterima.
\end{abstract}

Kata kunci: postpartum depression, dukungan sosial, ibu suku Jawa

${ }^{1}$ Korespondensi: Bunga Elsharon Wiyanto. Fakultas Psikologi Universitas Kristen Satya Wacana, Salatiga, Jawa Tengah, 50711. Email: bungaelsharon1999@gmail.com 
Kelahiran seorang anak merupakan hal yang membahagiakan dan ditunggu-tunggu oleh keluarga. Untuk mencapainya, seorang ibu melewati berbagai proses hingga sampai pada saat persalinan. Pasca persalinan menjadi hal yang penting, karena ibu akan berada pada masa transisi dari perubahan fisik dan psikologis ibu. Periode pasca persalinan ini seringkali berdampak buruk bagi kehidupan seorang ibu (Amalia et al., 2019). Di masa transisi, seorang ibu membutuhkan penyesuaian pada minggu-minggu awal pasca melahirkan. Selama proses penyesuaian, seorang ibu rentan terhadap stress, bahkan depresi. Hal itu disebabkan terjadinya perubahan-perubahan, baik fisik maupun psikologis (Tolongan et al., 2019). Gejala depresi yang dialami oleh ibu pasca melahirkan dikenal dengan sebutan postpartum depression (Damayanti, 2020).

World Health Organization (WHO) memperkirakan ada 10 per 1000 kelahiran hidup wanita yang mengalami depresi ringan pasca melahirkan dan depresi pasca melahirkan sedang atau berat berkisar 30 sampai 20 per 1000 kelahiran hidup (Soep dalam Tolongan et al., 2019). O'hara (2009) dan Primastika (2019) menyebutkan wanita mengalami depresi ringan sebesar $19,2 \%$ dan $7,1 \%$ berkemungkinan mengalami episode depresi berat pada tiga bulan pertama. Di Indonesia, prevalensi kejadian depresi pasca melahirkan berkisar 2,5\% hingga 22,3\% (Nurbaeti et al., 2019).

Depresi pasca melahirkan atau postpartum depression merupakan gejala afektif yang terjadi beberapa hari atau minggu setelah melahirkan dan ditandai dengan suasana hati yang tertekan, kecemasan berlebihan, susah tidur, dan perubahan berat badan (Kaplan \& Sadock's, 2015). Postpartum depression berasal dari reaksi biologis pasca melahirkan seperti perubahan hormon yang kemudian memengaruhi perubahan pada reaksi kimia di otak ditambah dengan kelelahan dan stress yang menyertai proses pasca melahirkan
(Callister dalam Sumantri \& Budiyani, 2017). Postpartum depression dapat berdampak negatif pada ibu, anak, dan keluarga. Seorang ibu yang mengalami postpartum depression memiliki minat dan ketertarikan terhadap bayinya berkurang, tidak mampu mengenali kebutuhan bayi, menolak untuk menyusui, mempunyai keinginan untuk melukai diri sendiri bahkan berpikir untuk bunuh diri, serta menyakiti bayinya sendiri (Tolongan et al., 2019). Kondisi ini merupakan hal yang serius, jika ibu tidak menyadari bahwa ia sedang mengalami depresi pasca melahirkan, maka dapat membahayakan dirinya sendiri dan perkembangan anaknya. Hal ini sependapat dengan Jacobsen (Stewart et al., 2003), depresi postpartum yang tidak diobati dapat memiliki efek jangka panjang yang merugikan bagi ibu dan anaknya. Bagi ibu, episode ini bisa jadi prekursor depresi kronis atau berulang sedangkan bagi anaknya, depresi ibu yang berkelanjutan menyebabkan permasalahan emosional, perilaku, kognitif dan interpersonal di kemudian hari. Oleh karena itu, sejak awal perlu deteksi postpartum depression supaya hal yang lebih buruk tidak terjadi.

Ibu yang baru saja melahirkan biasanya sekitar 70\% memiliki gejala depresi ringan yang pada 2-5 hari setelah melahirkan akan meningkat dan mereda dalam 2 minggu. Jika deteksi tidak dilakukan dengan cepat dan penanganan yang dilakukan terlambat, maka depresi yang semula ringan akan berkembang menjadi postpartum depression (Stewart \& Vigod, 2016). Tanda-tanda dan gejala-gejala depresi pasca persalinan umumnya sama dan berhubungan dengan depresi berat, termasuk suasana hati yang tertekan, anhedonia, energi yang rendah, dan ide untuk bunuh diri (Stewart et al., 2003). Dalam PPDGJ (Pedoman Penggolongan dan Diagnosa Gangguan Jiwa) edisi III, depresi postpartum didefinisikan sebagai gangguan jiwa yang berkaitan dengan masa nifas (6 minggu setelah pasca persalinan), 
yang tidak memenuhi kriteria lain, serta memenuhi kriteria episode depresi (Maslim, 2013). Kriteria dari episode depresi tersebut seperti afek depresif, mudah kelelahan, kehilangan minat, terganggunya waktu tidur, konsentrasi berkuang, dan menurunnya nafsu makan (Sari, 2020). Dalam Diagnostic and Statistical Manual $5^{\text {th }} E d$, onset umum postpartum depression terjadi 12 minggu setelah melahirkan (American Psychiatric Association, 2013).

Ada berbagai faktor yang menyebabkan depresi pasca melahirkan terjadi, antara lain: umur dan paritas, hormonal, pengalaman dalam proses persalinan, pelayanan kesehatan, dan dukungan sosial (Tolongan et al., 2019). Selain itu penyebab depresi pasca melahirkan dapat dipicu dari faktor internal maupun internal ibu, seperti; depresi dan kecemasan saat hamil, riwayat depresi, ekonomi yang rendah, tidak ada rasa menghargai diri sendiri, memiliki banyak anak, tidak memiliki pengalaman, usia ibu terlalu muda, hubungan pernikahan yang buruk, masalah pengasuhan anak, dan tidak adanya dukungan keluarga selama hamil serta setelah persalinan (Wurisastuti, 2020; Nurbaeti et al., 2019; Stewart et al., 2003). Di samping itu juga dari segi budaya, dimana ada konsep budaya patriarki yang masih mengakar kuat di Indonesia, secara khusus dalam budaya Jawa. Sistem patriarki menurut Budaya Jawa adalah memposisikan wanita lebih rendah daripada kaum laki-laki baik dalam sektor publik maupun rumah tangga. Seorang wanita dalam hal ini istri memiliki peran yang bersifat kerumahtanggaan yang mana harus mengurus berbagai hal yang berhubungan dengan rumah tangga, seperti memasak, mencuci baju dan piring, membersihkan rumah hingga mengasuh anak (Putri \& Lestari, 2015). Sementara suami bertanggung jawab untuk mencari nafkah bagi keluarga, pelindung, dan pengayom (Raharjo dalam Putri \& Lestari, 2015), sehingga tidak memiliki keharusan untuk melakukan atau membantu dalam pekerjaan rumah. Ketidaksiapan dalam menghadapi tuntutan berbagai peran yang didapat setelah melahirkan dapat menimbulkan kecemasan dan kelelahan.

Saat ibu mengurus bayinya, kemudian suami tidak mau mengerti dan tidak mengetahui cara yang harus dilakukannya dalam membantu merawat bayi atau membantu melakukan pekerjaan rumah, akan membuat ibu merasa tidak mendapatkan dukungan dari suaminya dan kelelahan sendiri dalam menjalankan perannya sebagai ibu (Kumampung, 2020). Ibu juga merasa lebih tertekan bila orangtua ataupun mertua banyak memberikan komentar karena merasa lebih berpengalaman dan terlalu ikut campur soal pengurusan bayi. Hal ini akan menyebabkan ibu merasa tidak dapat menjalani perannya dengan baik, merasa tidak dihargai, tidak percaya diri, lebih sensitif, dan memiliki perasaan bersalah (Kumampung, 2020). Selain itu, ibu yang merawat bayinya sendiri tanpa bantuan dari orang lain atau seorang yang lebih berpengalaman, seperti orangtua, mertua, atau pengasuh anak akan menyebabkan munculkan kecemasan dan kelelahan yang akan berkembang menjadi stress. Jika dibiarkan maka dapat menyebabkan depresi postpartum.

Dalam suatu kasus di Jawa Tengah yang dimuat dalam Tribunnews, ada seorang ibu yang melompat dari jembatan Sungai Serayu bersama dengan anaknya yang berusia 4 bulan. Sebelum kejadian ini terjadi, Ikhsan Juwadi selaku ketua RT setempat mengungkapkan bahwa korban menjadi lebih pemurung setelah melahirkan anaknya. Selain itu, Kustiono ayah korban mengungkapkan bahwa korban sempat kesulitan memberi ASI dan menjaga jarak dengan anak yang baru dilahirkan. Dalam kasus tersebut Dr. Ugung Dwi Ario Wibowo, M.Si, Dosen Fakultas Psikologi Universitas Muhammadiyah Purwokerto (UMP) menduga bahwa korban mengalami depresi paska melahirkan. Dimana indikasi 
dari depresi postpartum, yaitu: penderitanya akan menutup diri, murung, berhalusinasi, muncul perasaan ingin menyakiti dirinya sendiri atau anaknya hingga muncul keinginan untuk bunuh diri. Oleh karena itu, Ugung menyatakan bahwa pendampingan dari orang di sekitar ibu pasca melahirkan sangatlah dibutuhkan untuk dapat menolong ibu dari depresi pasca melahirkan (Suhendi, 2019). Berdasarkan kasus di atas, pendampingan memang sangatlah penting untuk ibu pasca melahirkan dan salah satu bentuk pendampingan yang bisa dilakukan berupa pemberian dukungan sosial dari lingkungan sekitar ibu (Utomo \& Sudjiwanati, 2018).

Dukungan sosial mengacu pada kesenangan yang dirasakan, kenyamanan, kepedulian, penghargaaan yang diterima, dan bantuan dari orang lain maupun kelompok sosial lainnya (Sarafino \& Smith, 2011). House (dalam Marmer, 2016; Utomo \& Sudjiwanati, 2018) menyatakan bahwa dukungan sosial merupakan suatu bentuk dukungan atau bantuan yang melibatkan pertukaran sumber sosial dari masing-masing individu. Dukungan sosial yang diberikan dapat memberikan ketenangan, perasaan diperhatikan dan dicintai, serta timbul rasa percaya diri dalam diri individu. Dukungan sosial dapat diterima dari siapa saja, baik dari pasangan, orangtua, mertua, dan orang lain di luar keluarga maupun teman (Hopkins \& Campbell, 2008). Pemberian dukungan sosial dari orang terdekat sangatlah membantu seseorang untuk dapat mengatasi tekanan psikologis di masa-masa sulit dan menekan (Taylor, 2012).

Dukungan sosial menurut Smet (1994 dalam Marmer, 2016) dibagi menjadi empat dimensi, yaitu; dukungan emosional, dukungan penghargaan, dukungan instrumental, dan dukungan informatif. Dukungan emosional meliputi kepedulian, ungkapan emosi, dan perhatian pada ibu, seperti ungkapan rasa cinta dari pasangan atau keluarga dan rasa empati serta dorongan supaya ibu yang baru meahirkan merasa dihargai. Dukungan penghargaan dengan memberikan penghargaan positif atau dorongan untuk maju, seperti memberi pujian dan semangat dari orang terdekat ibu untuk kerja keras ibu dalam merawat bayi. Dukungan instrumental yang melibatkan bantuan atau pertolongan secara langsung, seperti membantu untuk menjaga anak atau membantu dalam melakukan pekerjaan rumah. Dukungan informatif dengan memberikan nasihat, petunjuk, saran-saran, maupun umpan balik yang dibutuhkan individu, seperti memberikan bimbingan atau pengarahan cara merawat bayi. Selain itu, Sarafino (dalam Lesmana \& Setiawan, 2017) juga menyatakan bahwa ada empat bentuk dukungan sosial, yaitu dukungan emosional yang melibatkan rasa empati, kepedulian, perhatian, hal positif, dan dorongan pada individu; dukungan instrumental yakni bantuan secara langsung berupa bantuan finansial atau membantu penyelesaian pekerjaan rumah; dukungan informasional berupa pemberian saran, nasihat, arahan, atau umpan balik tentang tindakan individu; dan dukungan persahabatan berupa ketersediaan orang lain untuk bersama dengan individu dalam menjalani aktifitasnya. Dalam pemberian dukungan sosial disesuaikan dengan keadaan dari individu tersebut, sehingga lebih efektif dan bermanfaat.

Seorang yang menerima dukungan sosial akan mengurangi tekanan emosional yang dialami, ketika merasa diperhatikan dan dibantu. Sama halnya dengan seorang ibu pasca melahirkan akan dapat bertahan dan terhindar dari pengaruh negatif pasca melahirkan, dalam hal ini postpartum depression ketika merasa diperhatikan oleh orang sekitarnya (significant others), sehingga ibu tidak merasa sendiri (loneliness) dalam menghadapi masa-masa transisi. Hal itu diperkuat oleh hasil penelitian sebelumnya (Sulistyaningsih \& Wijayanti, 2020) bahwa ada hubungan yang signifikan antara variabel dukungan keluarga dengan tingkat depresi pada ibu 
postpartum depression. Penelitian lain oleh Fairus \& Widiyanti (2014), juga menunjukkan bahwa dukungan suami secara signifikan berkaitan dengan kejadian depresi pasca melahirkan pada ibu nifas. Kemudian penelitian yang dilakukan oleh Vaezi et al (2018), pada ibu yang baru pertama kali melahirkan di Iran, menyatakan bahwa semakin luas jaringan sosial ibu maka semakin sedikit postpartum depression terjadi.

Berdasarkan hasil-hasil penelitian sebelumnya, dapat diketahui adanya dukungan sosial yang kuat dari orang terdekat sekitar ibu dapat menurunkan kemungkinan terjadinya postpartum depression. Dukungan sosial dari orang terdekat yang diberikan oleh suami dapat berupa perhatian, bantuan, ataupun dukungan baik secara materil seperti pakaian, susu, dan makanan, serta emosional seperti rasa nyaman, ketenangan, dicintai, dihargai, dan dorongan. Hal itu tentunya akan membuat istri merasa lebih aman dan termotivasi (Cohen \& Syme dalam Sitorus, 2020). Selain itu, dukungan sosial yang diberikan suami dapat membuat ibu lebih terbuka dalam mengutarakan yang dirasakannya, sehingga mempermudah dalam menyelesaikan permasalahan, mengurangi rasa cemas, dan menurunkan tingkat stress pada ibu pasca melahirkan (Eker dalam Tambag et al., 2018). Namun, dukungan sosial seharusnya tidak hanya diberikan oleh suami, tapi juga diberikan oleh orang terdekat di sekitarnya, seperti: orang tua, mertua, dan teman-teman terdekatnya. Hal ini sependapat dengan Friedman (1998) yang mengemukakan bahwa baik keluarga inti maupun keluarga besar berfungsi sebagai sistem pendukung bagi anggotaanggotanya. Dalam hal ini ibu termasuk dalam anggota yang dimaksudkan. Dukungan sosial yang diberikan keluarga atau orang terdekat ibu akan membuat ibu merasakan bahwa orang di sekitarnya siap memberikan bantuan dan pertolongan jika dibutuhkan (Friedman, 2010). Oleh karenanya, harus ada kerjasama dari semua pihak untuk dapat menjauhkan ibu dari kecemasan dan stress yang bisa berpotensi menjadi postpartum depression.

Namun pemberian dukungan sosial sering kali tidak diberikan pada ibu pasca melahirkan, karena masyarakat Jawa memandang bahwa kesulitan yang dialami oleh ibu setelah melahirkan merupakan bagian yang memang seharusnya dialami oleh setiap perempuan dalam artian ibu. Hal ini sejalan dengan Ahli filsafat UGM Damardjati Supadjar (Handayani dalam Pramudita, 2016) yang mengungkapkan bahwa kata "wanita" ("wani" yaitu berani dan "tapa" yaitu menderita) berarti sosok yang berani menderita. Ketahanan wanita untuk menderita dianggap sebagai bagian dari hidup wanita (Handayani dalam Triratnawati, 2005). Selain itu, adanya konsep patriarki pada kebudayaan Jawa yang masih mengakar kuat, yang mana konsep tersebut membentuk sikap peran gender tradisional dalam masyarakat Jawa yang menganggap pria lebih superior dibandingkan perempuan (Olson \& Defrain dalam Putri \& Lestari, 2015). Selain itu, dalam istilah Jawa peran istri adalah kanca wingking, yang berarti teman belakang dalam mengurus rumah tangga. Istilah ini berarti dalam sektor domestik, tugas dan tanggung jawab dalam mengerjakan pekerjaan rumah tangga dan mengurus anak dibebankan kepada istri. Seorang perempuan (istri) diharuskan bisa melakukan 3M; macak, masak, dan manak (bersolek, memasak, serta memberikan keturunan). Walaupun sedang dalam kondisi pasca melahirkan, dalam hal ini seorang istri tetap dituntut untuk melakukan hal tersebut, sementara suami tidak memiliki tanggung jawab untuk melakukannya atau ikut membantu. Hal tersebut dikarenakan pandangan dari suami atau lelaki Jawa yang menganggap bahwa istrinya tidak berada pada tataran yang sama dengan dirinya dan memandang bahwa istri merupakan sosok yang harus melayani (Sardjono, 1992). Perempuan 
yang melaksanakan peran baik sebagai ibu dan istri tersebut dituntut untuk tetap bersikap sabar, menerima, dan ikhlas (Endraswara, 2003). Berdasarkan latar belakang tersebut, penulis akan menguji kembali apakah ada hubungan antara dukungan sosial dengan postpartum depression pada ibu suku Jawa pasca melahirkan. Hipotesis yang diajukan adalah ada hubungan negatif antara dukungan sosial dengan postpartum depression pada ibu suku Jawa pasca melahirkan. Yang mana semakin tinggi tingkat dukungan sosial maka semakin rendah tingkat postpartum depression yang dialami oleh ibu suku Jawa pasca melahirkan. Begitu juga sebaliknya, semakin rendah tingkat dukungan sosial maka semakin tinggi tingkat postpartum depression yang dialami oleh ibu suku Jawa pasca melahirkan.

\section{METODE}

Variabel yang digunakan dalam penelitian ini yaitu dukungan sosial yang merupakan variable bebas dan postpartum depression yang merupakan variable tergantung. Dukungan sosial mengacu pada kesenangan yang dirasakan, kenyamanan, kepedulian, penghargaaan yang diterima, dan bantuan dari orang lain maupun kelompok sosial (Sarafino \& Smith, 2011). Semakin tinggi skor yang dapatkan maka semakin tinggi dukungan sosial yang diberikan oleh ibu pasca melahirkan, namun semakin rendah skor yang didapatkan maka semakin rendah dukungan sosial yang diberikan pada ibu pasca melahirkan.

Postpartum depression atau depresi pasca melahirkan merupakan gejala afektif yang terjadi beberapa hari atau minggu setelah melahirkan dan ditandai dengan suasana hati yang tertekan, kecemasan berlebihan, susah tidur, dan perubahan berat badan (Kaplan \& Sadock's, 2015). Semakin tinggi skor yang didapatkan maka semakin tinggi tingkat depresi pasca melahirkan yang dialami oleh ibu, sedangkan semakin rendah skor yang didapatkan maka semakin rendah tingkat depresi pada ibu pasca melahirkan.

Penelitian ini merupakan penelitian kuantitatif korelasional. Partisipan dalam penelitian ini merupakan ibu pasca melahirkan yang dipilih dengan menggunakan teknik purposive sampling, dengan kriteria pertimbangan: (1) suku Jawa; (2) berusia 20-35 tahun; (3) minimal 1 minggu dan maksimal 1 bulan pasca melahirkan (4) skor EPDS >10 yang merupakan skor minimum seseorang yang termasuk mengalami kecenderungan depresi pasca persalinan. Berdasarkan kriteria dari total 52 partisipan, data yang dapat diolah hanya sebanyak 34 partisipan $(65.38 \%)$ dengan mean $=27,38$ dan $\mathrm{SD}=$ 4,65 pada usia. Hal ini dikarenakan hanya 34 partisipan yang memiliki skor pada alat ukur EDPS >10, skor itu merupakan nilai minimum seseorang dikatakan mengalami kecenderungan depresi pasca melahirkan (Guedeney et al., 2000).

Pengambilan data dalam penelitian ini dilakukan dengan membagikan kuesioner kepada partisipan dengan menggunakan dua cara, yaitu; online dengan menggunakan google form dan offline dengan mendatangi sejumlah pusat kesehatan seperti, bidan dan rumah sakit. Tedapat dua skala yang digunakan dalam kuisoner, yaitu: Edinburgh Postnatal Depression Scale (EPDS) yang sudah diadaptasikan ke dalam Bahasa Indonesia dalam penelitian Marmer (2016) dan Postpartum Social Support Questionnaire (PSSQ) yang diadaptasi dan diterjemahkan kedalam Bahasa Indonesia dari skala Hopkins \& Campbell (2008). EDPS merupakan instrumen skrining yang dirancang untuk mendeteksi depresi pada ibu pada periode postpartum awal, yaitu seminggu sampai sebulan pasca melahirkan (Soep, 2011). Alat ukur ini terdiri dari 10 aitem pernyataan dengan empat pilihan jawaban yang masing-masing mempunyai skor 0-3. Kemudian untuk dukungan sosial diukur menggunakan Postpartum Social 
Support Questionnaire (PSSQ) untuk meneliti peran dukungan sosial dalam adaptasi pasca persalinan (Hopkins \& Campbell, 2008). Jumlah aitem dalam alat ukur ini terdiri dari 50 aitem yang terbagi dalam 4 subscales: dukungan pasangan, dukungan orangtua, dukungan mertua, dan dukungan teman dan orang diluar keluarga yang dijawab menggunakan skala likert dengan 7 alternatif jawaban yang disusun, 1 "Hampir tidak pernah" sampai 7 "Sangat sering".

Peneliti melakukan analisis seleksi aitem dan uji reliabilitas pada masing-masing skala dengan menggunakan bantuan program SPSS versi 2.5. Untuk uji seleksi aitem peneliti menggunakan batasan koefisien korelasi item-total sebesar 0,25 (Azwar, 2017), sedangkan untuk uji reliabilitas dilakukan dengan teknik Alpha Cronbach. Pada skala EPDS peneliti melakukan uji seleksi aitem sebanyak 2 putaran dan didapatkan hasil bahwa 2 dari 10 aitem dinyatakan gugur, sehingga terdapat 8 aitem yang digunakan dalam penelitian ini. Sementara pada skala PSSQ, terdapat 6 dari 50 aitem yang dinyatakan gugur, sehingga terdapat 44 aitem yang digunakan dalam penelitian ini. Aitem yang gugur berada pada subscale dukungan suami dengan uji seleksi aitem sebanyak 4 putaran. Pada uji reabilitas skala EPDS didapati nilai $\alpha=0,862$ dan nilai $\alpha$ skala dukungan sosial sebesar 0,879. Nilai tersebut menurut (Nunnally, 1978) sudah cukup baik, karena melewati 0,70 yang merupakan batas minimal reliabilitas dari skala penelitian.

Pada penelitian ini dilakukan perhitungan uji asumsi yaitu; uji normalitas dan uji linieritas. Untuk uji normalitas, peneliti menggunakan uji normalitas shapiro-wilk dikarenakan sample kurang dari 50. Bedasarkan hasil uji normalitas terdapat data pada variabel postpartum depression (EPDS) yang tidak memenuhi asumsi normalitas yakni sebesar $0,000(p<0,05)$, sedangkan pada variabel dukungan sosial (PSSQ) menghasilkan skor signifikansi sebesar $0,787 \quad(p>0,05)$ yang artinya sebaran data memenuhi asumsi normalitas, sehingga uji hipotesis menggunakan teknik non parametrik. Hal ini sesuai dengan pendapat Sugiyono (2013) yang menyatakan bahwa jika ada data yang berdistribusi tidak normal, maka menggunakan teknik non parametrik. Kemudian untuk mengetahui linearitas antara kedua variabel dalam penelitian, dilakukan uji linieritas. Hasilnya menunjukkan dalam penelitian ini terdapat linieritas antara variabel dukungan sosial dengan postpartum depression dengan nilai sig. deviation from linearity adalah 0,969 ( $\mathrm{p}>0,05)$.

\section{HASIL DAN DISKUSI}

Hasil penelitian terhadap uji hipotesis penelitian dengan menggunakan uji spearman's rho correlation menunjukan koefisien korelasi $(\mathrm{r})=0,318$ dengan nilai sig $=0,219(\mathrm{p}<0,05)$, yang berarti tidak terdapat hubungan negatif antara dukungan sosial dan postpartum depression. Hal ini berarti variasi dukungan sosial tidak memiliki peran pada variasi postpartum depression. Dengan demikian hasil tersebut menunjukan bahwa hipotesis dalam penelitian ini ditolak. Hasil penelitian diatas tidak sesuai dengan Sulistyaningsih \& Wijayanti (2020) yang menyatakan adanya hubungan yang signifikan antara dukungan keluarga dengan tingkat depresi pada ibu postpartum depression. Kemudian dengan penelitian lain oleh Fairus \& Widiyanti (2014), yang juga menunjukkan bahwa dukungan suami secara signifikan berkaitan dengan kejadian depresi pasca melahirkan pada ibu nifas. Selanjutnya tidak sesuai juga dengan studi yang dilakukan Vaezi et al (2018) pada ibu yang baru pertama kali melahirkan di Iran, menyatakan bahwa semakin luas jaringan sosial ibu maka semakin sedikit postpartum depression terjadi. Oleh karena itu pada penelitian ini, diketahui bahwa dukungan sosial tidak memiliki peran pada penurunan maupun peningkatan dari postpartum 
depression, sehingga ada faktor-faktor lain yang menjadi penyebab postpartum depression dapat dialami oleh ibu pasca melahirkan. Hasil penelitian tersebut sejalan dengan penelitian oleh Ege et al yang dilakukan pada ibu pasca melahirkan di Turkey, bahwa gejala depresi postpartum berkorelasi negatif dengan dukungan sosial dan berhubungan dengan faktor lainnya (Ozmen, 2014).

Faktor lain yang menjadi penyebab dari postpartum depression menurut penelitian Putriarsih et al (2018) adalah kehamilan yang tidak diinginkan atau direncanakan, yang berhubungan langsung secara signifikan dengan postpartum depression. Ibu yang tidak menginginkan kehamilannya memiliki kemungkinan 1,74 kali terkena gejala postpartum depression dibandingkan dengan ibu yang menginginkan kehamilannya (Putriarsih et al., 2018). Sebuah studi oleh Limlomwongse dan Liabsuetrakul juga menemukan bahwa sikap negatif terhadap kehamilan ini melipatgandakan risiko postpartum depression (Mehta \& Mehta, 2014). Pernyataan tersebut tidak sesuai dengan hasil wawancara terbuka pada ibu saat mengisi kuesioner, yang menyatakan bahwa kehamilan yang dialami memang direncanakan dan diinginkan. Faktor lain yang menjadi penyebab dari postpartum depression menurut Thompson dan Fox adalah faktor biologis. Hal ini disebabkan oleh menurunnya terlalu cepat atau terlalu lambat kadar hormon progesteron, estrogen (estradiol dan estriol), kortisol, prolaktin yang memunculkan depresi postpartum, semakin besar penurunan kadar estrogen dan progesterone, memperkuat kecenderungan ibu dapat mengalami depresi dalam waktu 10 hari pertama persalinan (Anggarini, 2019).

Hensaw (2003, dalam Rahayu \& Ferian, 2020) menyatakan bahwa kepribadian ibu dapat menjadi penyebab depresi postpartum. Pernyataan tersebut berkaitan dengan penelitian Rahayu \& Ferian (2020), yang mana kepribadian negatif ibu 54 kali dapat menyebabkan postpartum depression. Sebagai contoh kepribadian negatif adalah kepribadian neurotisme tinggi yang menyebabkan seseorang cenderung merasa cemas, mudah marah, mengasihani diri sendiri, sadar diri, emosional, dan rentan terkena gangguan stress (Feist \& Feist, 2018). Hal ini sesuai dengan wawancara terbuka dengan ibu saat mengisi kuesioner yang menyatakan bahwa ibu mengalami perasaan cemas dan stress dikarenakan harus menjalani persalinan dan merawat bayi ditengah pandemi. Selain dari tipe kepribadian, efikasi diri yang dimiliki ibu pasca melahirkan juga berhubungan langsung pada postpartum depression. Efikasi diri adalah kepercayaan terhadap kemampuannya untuk mengendalikan fungsi dan peran dalam hal ini sebagai ibu (Putriarsih et al., 2018). Bandura menyatakan bahwa rasa kepercayaan diri seseorang bertindak dalam mengurangi persepsi reaksi terhadap stress dan depresi, sehingga semakin ibu berhasil dalam menangani tugas dan tuntuan sebagai ibu, semakin kecil kecenderungan mengalami stress dan depresi (Putriarsih et al., 2018).

Sama halnya dengan hasil kategorisasi penelitian ini, pada variabel postpartum depression responden berada dalam kategori sedang dengan presentase $64,71 \%$ dan nilai rata-rata 12,12 . Hal ini dapat disebabkan oleh berbagai faktor salah satunya rendahnya dukungan sosial. Akan tetapi, hasil tesebut tidak sejalan dengan kategorisasi pada subscale variable dukungan sosial suami dan orang tua yang dominan berada pada kategori sangat tinggi sebesar $64,70 \%$ dengan nilai rata rata 57,21 untuk dukungan suami dan $44,12 \%$ dengan nilai rata-rata 51,59 untuk dukungan orangtua. Sementara untuk dukungan dari mertua hasilnya tidak ada yang dominan dan seimbang pada kategori tinggi, rendah, dan sangat rendah sebesar $26,47 \%$ dengan nilai rata-rata 30,74, lalu untuk kategorisasi teman dan orang diluar keluarga dominan pada kategori rendah $32,35 \%$ dengan nilai 
rata rata 58,62. Perbedaan hasil dari subscale dukungan sosial dikarenakan faktor kedekatan hubungan antara masingmasing subscale dengan ibu pasca melahirkan. Berdasarkan hasil wawancara terbuka pada ibu saat mengisi kuesioner, ibu merasa mendapat dukungan sosial yang tinggi dari suami dan orangtua karena mereka berada dekat dengan lingkungannya. Sedangkan ibu kurang mendapatkan dukungan sosial dari mertua dan teman karena mereka tinggal dilingkungan yang jauh, sehingga dukungan sosial dari subscale tersebut kurang diharapkan. Hal ini sesuai dengan pendapat Utomo \& Sudjiwanati (2018) bahwa dukungan sosial banyak diperoleh dari lingkungan sekitar ibu yang terdekat, sehingga kedekatan dengan keluarga juga dapat menjadi salah satu faktor pemicu postpartum depression.

\section{SIMPULAN}

Pada penelitian ini diperoleh kesimpulan bahwa tidak ada hubungan negatif antara dukungan sosial dan postpartum depression pada ibu suku Jawa pasca melahirkan. Artinya dukungan sosial tidak memiliki pengaruh dalam penurunan maupun peningkatan dari postpartum depression pada ibu suku Jawa. Oleh karena itu ada faktor lain yang mempengaruhi ibu berpotensi terkena postpartum depression, yaitu: faktor biologis, faktor kepribadian, efikasi diri, dan faktor kehamilan yang tidak direncanakan atau diinginkan.

Saran untuk ibu agar dapat mencegah depresi pasca melahirkan dengan cara meningkatkan kepribadiannya kearah yang lebih positif, seperti berfikir positif, tidak mudah cemas, tidak emosional dan mudah marah, serta membangun kepercayaan diri yang tinggi. Selain itu, ibu harus lebih terbuka kepada pasangan, keluarga, maupun orang lain dengan menceritakan keluhan ataupun kesulitan yang dialami selama mengurus bayi. Untuk lingkungan sosial dari ibu, diharapkan tetap memberikan dukungan sosial yang disesuaikan dengan kebutuhan dari ibu dan memperhatikan faktor-faktor lain yang berpotensi menyebabkan postpartum depression. Untuk penelitian diharapkan dapat membentuk kerjasama dengan satu instansi kesehatan (rumah sakit, puskesmas, atau bidan), sehingga mempermudah penyebaran kuesioner kepada subjek penelitian dan mendapat responden yang lebih banyak. Selain itu, perlu penelitian lanjutan tentang faktor budaya dalam hal ini budaya Jawa, untuk dapat mengetahui pengaruhnya pada postpartum depression pada ibu.

\section{REFERENSI}

Amalia, A., Ramadhana, M., \& Faradiba, A. T. (2019). Peran dukungan suami terhadap kecenderungan depresi paska melahirkan. Journal Psikogenesis, 7(1), 13-17. doi:10.24854/jps.v7i1.872

American Psychiatric Association. (2013). Diagnostic and statistical manual of mental disorders (5th ed.). doi:10.1016/B978-0-12-8093245.05530-9

Anggarini, I. A. (2019). Faktor-faktor yang berhubungan dengan depresi postpartum di Praktik Mandiri Bidan Misni Herawati, Husniyanti, dan Soraya. Jurnal Kebidanan, 8(2), 94104. doi:10.26714/jk.8.2.2019.94-104

Azwar, S. (2017). Metode penelitian psikologi (2nd ed.). Pustaka Pelajar.

Damayanti, R. (2020). Dukungan sosial dan depresi pascasalin: Studi metaanalisis. Jurnal Psikologi, 13(2), 236244. doi:10.35760/psi.2020.v13i2.3202

Endraswara, S. (2003). Falsafah hidup Jawa. Cakrawala.

Fairus, M., \& Widiyanti, S. (2014). Hubungan dukungan suami dengan kejadian depresi ostpartum pada ibu nifas. Jurnal Kesehatan Metro Sai Wawai, 7(1), 11-18. Diunduh dari https://ejurnal.poltekkes- 
tjk.ac.id/index.php/JKM/article/view/ 260

Feist, J., \& Feist, G. J. (2018). Theories of personality (9th ed.). McGraw-Hill.

Friedman, M. (1998). Keperawatan keluarga: Teori dan praktik (3rd ed.). EGC.

Friedman, M. (2010). Buku ajar keperawatan keluarga: Riset, teori, dan praktek (5th ed.). EGC.

Guedeney, N., Fermanian, J., Guelfi, J. D., \& Kumar, R. C. (2000). The Edinburgh Postnatal Depression Scale (EPDS) and the detection of major depressive disorders in early postpartum: Some concerns about false negatives. Journal of Affective Disorders, 61(1-2), 107-112. doi:10.1016/S0165-0327(99)00186-X

Hopkins, J., \& Campbell, S. B. (2008). Development and validation of a scale to assess social support in the postpartum period. Archives of Women's Mental Health, 11(1), 5765. doi:10.1007/s00737-008-0212-5

Kaplan, \& Sadock's. (2015). Synopsis of psychiatry: Behavioral sciences and clinical psychiatry (11th ed.). In Wolters Kluwer. doi:10.1176/ajp.149.7.972

Kumampung, D. R. (2020, Februari 27). Mengenal baby blues, sindrom yang diduga picu ibu bunuh bayi sendiri. Kompas. Diunduh dari https://lifestyle.kompas.com/read/202 0/02/27/110515120/mengenal-babyblues-sputriindrom-yang-didugapicu-ibu-bunuh-bayi-sendiri?page $=$ all

Lesmana, R., \& Setiawan, J. L. (2017). Hubungan antara social support dan resilience efficacy pada remaja atlet bulutangkis di Surabaya. Psychopreneur Journal, 1(1), 35-45.

Marmer, L. W. (2016a). Persepsi terhadap dukungan suami pada primipara yang mengalami depresi pasca melahirkan. In Universitas Airlangga Surabaya. Universitas Airlangga.

Marmer, L. W. (2016b). Persepsi terhadap dukunganmasl suami pada primipara yang mengalami depresi pasca melahirkan (postpartum depression). Universitas Airlangga.

Maslim, R. (2013). Buku saku diagnosis gangguan jiwa: rujukan ringkas dari PPDGJ-III dan DSM-V. Bagian Ilmu Kedokteran Jiwa Fakultas Kedokteran Unika Atma Jaya.

Mehta, S., \& Mehta, N. (2014). An overview of risk factors associated to post-partum depression in Asia. Mental Illness, 6(1), 14-17. doi:10.4081/mi.2014.5370

Nunnally, J. C. (1978). Psycometric theory. McGraw-Hill.

Nurbaeti, I., Deoisres, W., \& Hengudomsub, P. (2019). Association between psychosocial factors and postpartum depression in South Jakarta, Indonesia. Sexual and Reproductive Healthcare, 20, 72-76. doi:10.1016/j.srhc.2019.02.004

O'hara, M. W. (2009). Postpartum depression: What we know. Journal of Clinical Psychology, 65(12), 12581269. doi:10.1002/jclp.20644

Ozmen, D. (2014). Association between perceived social support and postpartum depression in Turkey. British Journal of Medicine and Medical Research, 4(10), 2025-2036. doi:10.9734/bjmmr/2014/6109

Pramudita, C. A. (2016). Konsep diri perempuan Jawa: Pembentukan dan orientasi. (Skripsi). Universitas Sanata Dharma, Yogyakarta.

Primastika, W. (2019, April 4). Depresi pasca-melahirkan dan bahaya bagi anak. Tirto. Diunduh dari https://tirto.id/depresi-pascamelahirkan-dan-bahaya-bagi-anak$\mathrm{dkSK}$.

Putri, D. P. K., \& Lestari, S. (2015). Pembagian peran dalam rumah tangga pada pasangan suami istri Jawa. Jurnal Penelitian Humaniora, 16(1), 72-85. doi:10.23917/humaniora.v16i1.1523

Putriarsih, R., Budihastuti, U. R., \& Murti, B. (2018). Prevalence and 
determinants of postpartum depression in Sukoharjo District, Central Java. Journal of Maternal and Child Health, 3(1), 395-408. doi:10.26911/thejmch.2017.03.01.02

Rahayu, F. T., \& Ferian, P. (2020). Hubungan dukungan suami dengan tingkat depresi ibu postpartum di Puskesmas Trauma Center Samarinda. Borneo Student Research, 2(1), 256261.

Sarafino, E. P., \& Smith, T. W. (2011). Health psychology biopsychosocial interactions (7th ed.). John Wiley \& Sons.

Sardjono, M. A. (1992). Paham Jawa: Menguak falsafah hidup manusia Jawa lewat karya fiksi mutakhir Indonesia. Pustaka Sinar Harapan.

Sari, R. A. (2020). Literature review: Depresi postpartum. Jurnal Kesehatan, 11(1), 167-173. doi:10.26630/jk.v11i1.1586

Sitorus, I. (2020). Pengaruh tingkat dukungan sosial suami terhadap kejadian postpartum depression pada ibu primipara. (Skripsi). Universitas Pelita Harapan, Tangerang.

Smet, B. (1994). Psikologi kesehatan. PT Gramedia Widiasarana Indonesia.

Soep, S. (2011). Penerapan edinburgh postpartum depression scale sebagai alat deteksi risiko depresi nifas pada primipara dan multipara. Jurnal Keperawatan Indonesia, 14(2), 95100. doi:10.7454/jki.v14i2.315

Stewart, D. E., Robertson, E., Phil, M., Dennis, C., Grace, S. L., \& Wallington, T. (2003). Postpartum depression: Literature review of risk factors and interventions. In Toronto Public Health. Diunduh dari http://www.who.int/mental_health/pr evention/suicide/lit_review_postpartu m_depression.pdf

Stewart, D. E., \& Vigod, S. (2016). Postpartum depression. The New England Journal of Medicine, 375(22), 2177-2186. doi:10.1097/01.nme.0000531872.482 83.ab

Sugiyono. (2013). Metode Penelitian Manajemen. Alfabeta.

Suhendi, A. (2019, April 28). Kasus ibu gendong bayi lompat dari jembatan sungai serayu: Perilaku aneh hingga pendapat ahli. Tribunnews. Diunduh dari

https://www.tribunnews.com/regional /2019/04/28/kasus-ibu-gendong-bayilompat-dari-jembatan-sungai-serayuperilaku-aneh-hingga-pendapatahli?page $=4$

Sulistyaningsih, D., \& Wijayanti, T. (2020). Hubungan dukungan keluarga dengan tingkat depresi postpartum di RSUD I. A Moeis Samarinda. Borneo Student Research, 1(3), 1641-1653.

Sumantri, R. A., \& Budiyani, K. (2017). Dukungan suami dan depresi pasca melahirkan. Insight: Jurnal Ilmiah Psikologi, $17(1), \quad 29$. doi:10.26486/psikologi.v17i1.682

Tambag, H., Turan, Z., Tolun, S., \& Can, R. (2018). Perceived social support and depression levels of women in the postpartum period in Hatay, Turkey. Nigerian Journal of Clinical Practice, 21(11), 1525-1530. doi:10.4103/njcp.njcp_285_17

Taylor, S. E. (2012). Social Support: A review. In The Oxford Handbook of Health Psychology (Issue March). doi:10.1093/oxfordhb/978019534281 9.013.0009

Tolongan, C., Korompis, G. E., \& Hutauruk, M. (2019). Dukungan suami dengan kejadian depresi pasca melahirkan. Jurnal Keperawatan, 7(2), 1-9.

Triratnawati, A. (2005). Konsep Dadi Wong menurut pandangan wanita Jawa. Humaniora, 17(3), 300-311. doi:10.22146/jh. 855

Utomo, Y. D. C., \& Sudjiwanati, S. (2018). Pengaruh dukungan sosial terhadap tingkat kecemasan ibu hamil di rumah sakit bersalin pemerintah kota Malang. Psikovidya, 22(2), 197-223. doi:10.37303/psikovidya.v22i2.117 
Psychopreneur Journal, 2020, 5(2): 68-79

ISSN 2598-649X cetak / ISSN 2598-6503 online

Vaezi, A., Soojoodi, F., Banihashemi, A.

T., \& Nojomi, M. (2018). The association between social support and postpartum depression in women: A cross sectional study. Women and Birth, 32(2), 238-242. doi:10.1016/j.wombi.2018.07.014

Wurisastuti, T. (2020). Peran dukungan sosial pada ibu dengan gejala depresi dalam periode pasca melahirkan. Buletin Penelitian Sistem Kesehatan, 23(3), 161-168. 